Florea : Jurnal Biologi dan Pembelajarannya, 8(1), 2021, 52-61

This is an open access article under the CC-BY-SA license (https://creativecommons.org/licenses/by-sa/4.o/)

ISSN 2355-6102(print), ISSN 2502-0404(online)

DOI : $10.25273 /$ florea.v8i1.8071

\title{
IDENTIFIKASI JENIS HAMA DAN PENYAKIT YANG SERING MENYERANG TUMBUHAN BUNGA MAWAR (Rosa hybrida L.) DI DAERAH MANYARAN
}

\author{
Ahmad Muzaki, Sri Wahyuni, Nur Rokhimah Hanik \\ ${ }^{1,2,3)}$ Jurusan Pendidikan Biologi, FKIP, Universitas Veteran Bangun Nusantara \\ *email:muzaki2145@gmai.com
}

\begin{abstract}
Bunga mawar merupakan tanaman hias yang dikenal masyarakat luas. Bentuk bunganya yang sangat indah membuat bunga mawar banyak yang membudidayakannya. Namun disisi lain ternyata tanaman bunga mawar mudah sekali sering diserang oleh berbagai macam penyakit, penyakit tersebut dapat diketahui dari gejala-gejala yang ditimbulkannya. Pada penelitian ini bertujuan untuk mengetahui penyakit yang terdapat ditanaman bunga mawar. Sehingga dengan adanya penelitian ini bisa mempermudah masyarakat dalam mengenali dan mengatasi gejala penyakit yang muncul pada tanaman bunga mawar. Penelitian ini menggunakan metode Observasi Pengamatan dan Wawancara, dimana meneliti gejala-gejala penyakit yang timbul pada tumbuhan bunga mawar dengan meneliti setiap bagian pada tanaman bunga mawar. Sempel yang digunakan terdapat 10 jenis bunga mawar.Penelitian ini menghasilkan berbagai temuan diantaranya pada daun terdapat hama tepung, tungau dan ulat daun. Sedangkan pada batang tanaman bunga mawar terdapat jamur upas yang membuat batang jika terlalu lama terjangkit hama ini akan membusuk dan mati. Pada bunga mawar terdapat hama Thirps dan pembusukan pada bunga.
\end{abstract}

Kata kunci :Tanaman Hias, Bunga mawar, Hama, Penyakit

\section{PENDAHULUAN}

Mawar (Rosa hybrida) merupakan tanaman hias bunga yang banyak digemari karena keindahan dan wanginya bunga. Mawar merupakan tanaman hias bunga berupa herba dengan batang berduri. Mawar bukan tanaman asli Indonesia, berasal dari dataran China. Dalam perkembangannya, menyebar luas di berbagai daerah, termasuk ke Indonesia. Di Indonesia, bunga Mawar dinikmati sebagai bunga potong atau digunakan untuk upacara adat dan sebagai bunga tabur.(Amiarsih et al., 2006)

Bunga mawar sangat pantas menyandang julukan si "Ratu Bunga" karena hampir semua orang menyukai dan mengenal mawar. Warna bungayang cantik menawan dengan aneka ragam warna warni Seakan menghidupkan suasana taman menjadi semarak, ditambah lagi pesona harumnya yang semerbak wangi. Bunga mawar dikenal mempunyai banyak varietas sehingga disebut Rosaceae atau keluarga mawar mawaran. Kemajuan teknologi semakin membuat tanaman bunga mawar beraneka ragam dengan warna warninya mulai dari merah, ungu, hitam dan bahkan campuranbeberapa warna. Disamping itu kelopak bunganya juga semakin variatif, dariyang berkuntum tunggal, ganda sampai ya ng bertumpuk.(Mill, 1952)

Mawar (Rosa hybrida L.) merupakan salah satubunga yang paling banyak diminati masyarakat karena penampilannya yang cantik dan indah serta aromanya yang harum dan khas, sehingga dijuluki queen of flower. Mawar banyak dipakai dalam bentuk bunga tangkai untuk upacara atau hadiah pada hari-hari penting, dan menurut kegunaannya dapat dikelompokkan menjadi bunga potong, mawar taman, dan mawar tabur.(Hydrodistillation, 2015)

Bunga mawar atau Rosa hybrida termasuk ke dalam famili Rosaceae yang menjadi salah satu komoditas tanaman hias yang banyak dibudidayakan dan diusahakan di Indonesia karena memiliki nilai ekonomi yang tinggi. Bunga mawar banyak dimanfaatkan sebagai tanaman hias pot, bunga potong, tanaman penghias taman, 
Florea : Jurnal Biologi dan Pembelajarannya, 8(1), 2021, 52-61

This is an open access article under the CC-BY-SA license (https://creativecommons.org/licenses/by-sa/4.0/)

ISSN 2355-6102(print), ISSN 2502-0404(online)

DOI : $10.25273 /$ florea.v8i1.8071

selain itu mawar juga digunakan sebagai bunga tabur (rampai) dan bahan industri kosmetik dan pewangi(Farisi et al., 2019).

Tanaman mawar umumnya merupakan tanaman perdu, batangnya berduri dengan tinggi tanaman antara 0.3 sampai 0.5 meter. Berakar tunggang dengan banyak cabang akar seperti serat dan akar rambut yang menyerupai benang. Daun mawar merupakan daun majemuk dengan 3 atau 5 berselang dan bersirip ganjil. Bunga ada yang tunggal dan ada pula yang tersusun indah dalam bentuk payung dengan perhiasan bunga setiap lingkaran 4-5 helai. Warna bunga bervariasi dari putih, merah, merah muda dan ungu muda. Buah mawar adalah buah yang di dalamnya terdapat biji.(Proklamasiningsih et al., 2016)

Permintaan bunga mawar di pasar dalam negeri cenderung meningkatterus-menerus, terutama di kota-kota besar. Kota Jakarta menyerap bungaterbesar dengan omset dan peredaran uang mencapai 25,8 miliar per tahun. Permintaan bunga mawar tidak kurang dari 20000 kuntum per hari. Keadaan ini memberikan gambaran cerah

bagi kalangan wirausahawan atau peminat bisnis lainnya diberbagai daerah di Indonesia (Astrilia Damayanti dan Endah Ayu Fitriana Program, 2015)

Bunga mawar yang dijadikan sebagai tanaman budidaya biasanya memiliki nilai jual sebagai bunga hias, bunga potong, dan diambil ekstraknya.Sebagai bunga potong, mawar mempunyai nilai ekonomi yang cukup tinggi dan dalam kegiatan perdagangan bunga potong memberikan peringkat pertama yang terjual setiap harinya. (Bambang Yuwono, Yuli Fauziah, 2008)

Oleh karena itu dari berbagai manfaat unggulan yang dipunyai oleh bunga mawar menjadikan bunga mawar menjadi salah satu tanaman hias favorit dikalangan masyarakat. Banyak sekali dari kalangan masyarakat yang berusaha untuk membudidayakannya.
Namun disisi lain, dalam membudidayakan tanaman hias bunga mawar ternyata tidaklah begitu mudah. Banyak sekali tantangantantangan yang harus dihadapi dalam membudidayakan tanaman hias bunga mawar utamanya dalam menghadapi gejala hama dan penyakit yang sering menyerang tanaman bunga mawar. Adapun jenis hama dan penyakit yang menyerang sangat beragam. Oleh karena itu untuk mengetahui jenis mawar beserta penyakitnya maka perlu dilakukan identifikasi.(Werdini ngsih, 2007)

Beberapa jenis hama dan penyakit yang sering menyerang tanaman bunga mawar yaitu yang pertama adalah Hama Thrips, berukuran sangat kecil sekitar $1 \mathrm{~mm}$, warnanya kuning kecoklatan. Menjadi hama karena menghisap cairan pada bunga, daun, dan cabang dari tanaman sehingga menyebabkan tanaman mawar mati (Dwiyanti, 2018)

Yang kedua adalah Hama Rayap, meneyarang bagian akar pada bunga mawar terutama yang ditanam di kebun. Yang ketiga adalah Hama Tungau, jenis hama yang sering kali ditemukan yaitu Tetranychus telarius. Berukuran sangat kecil $(0,3 \mathrm{~mm})$, berwarna merah, hijau atau kuning. Hama tungau ini sangat suka dengan kondisi udara yang lembabdan sirkulasi udara yang panas. Gejala tanaman yang terserang hama ini yaitu ada titik abu-abu kecoklatan pada bagian daun atau pucuk tanaman yang dihisap cairan sel tanaman.(Hikmah et al., 2018)

Hama yang ke empat adalah ulat daun, bagian tanaman mawar yang diserang oleh hama ini adalah daun dan kuncup bunga sehingga menjadi rusak dan berlubang.(Sari et al., 2018)

Hama yang kelima adalah Belalang (Valanga nigricornis), gejala serangan belalang antara lain seperti daun menjadi sobek dan berlubang-lubang besar. (Maryani, 2013) 
Florea : Jurnal Biologi dan Pembelajarannya, 8(1), 2021, 52-61

This is an open access article under the CC-BY-SA license (https://creativecommons.org/licenses/by-sa/4.0/)

ISSN 2355-6102(print), ISSN 2502-0404(online)

DOI : $10.25273 /$ florea.v8i1.8071

Penyakit yang menyerang bunga mawar adalah penyakit bercak daun, penyebab penyakit ini disebabkan oleh Cercospora rosicola atau Alternaria. Gejala serangan akibat penyakit ini yaitu berupa bercak coklat atau kehitaman pada daun tua. (Suhardi, 2007)

Selain itu ada penyakit Tepung yang disebabkan oleh jamur Oidium. Gejala yang terlihat pada tanaman berupa tepung atau lapisan putih pada permukaan daun . akibat serangan penyakit ini, daun akan menjadi kemerahan, kemudian menguning dan akhirnya gugur(Ayu et al., 2016)

Oleh karena itu dari banyaknya jenis hama dan penyakit yang menyerang tumbuhan bunga mawar menjadikan hal tersebut sebagai fokus utama objek kajian pada penelitian ini. Penelitian ini bertujuan untuk mengetahui serta mengidentifikasi secara jelas jenis hama dan penyakit yangmenyerang tanaman bunga mawar. Selain itu dengan adanya penelitian ini diharapkan mampu membawa kebermanfaatan kepada masyarakat khususnya dalam menghadapi tantangantantangan dalam usaha budidaya tumbuhan bunga mawar.

\section{METODE}

\section{PENELITIAN}

\section{Waktu dan Tempat}

Kegiatan penelitian ini dilaksanakan pada selama 2 minggu yaitu pada mulai tanggal 28 November 2020 sampai tanggal

13 Desember 2020. Kegiatan penelitian ini dilaksanakan di daerah kecamatan Manyaran, Kabupaten Wonogiri.

\footnotetext{
Alat dan Bahan

Kegiatan penelitian ini menggunakan beberapa alat pendukung, diantaranya seperti kamera untuk mengambil gambar dan alat tulis untuk mendata. Bahan yang
}

digunakan dalam penelitian ini adalah tanaman bunga mawar.

\section{Metode}

Kegiatan penelitian ini dilaksanakan dengan menggunakan metode Observasi Pengamatan dan Wawancara. Metode ini dilakukan melalui beberapa tahapan, diantaranya :

1. Menyiapkan peralatan yang akan digunakan dalam penelitian.

2. Mencari tanaman bunga mawar yang digunakan sebagai objek kajian penelitian.

3. Mengamati dan mendata hama maupun penyakit yang terdapat pada tanaman bunga mawar. Kegiatan ini dilakukan secara bertahap berdasarkan bagianbagian tanaman (akar, batang, daun, bunga)

4. Mengidentifikasi hama maupun penyakit yang terdapat pada tanaman bunga mawar dengan mencocokkan sumber pustaka yang tersedia.

Kegiatan wawancara dilaksanakan dengan mecari sumber informasi kepada pemilik tanaman dengan tujuan untuk mencari serta memperkuat data tambahan yang diperoleh dari kegiatan observasi pengamatan sebelumnya.

\section{HASIL DAN PEMBAHASAN Hasil}

Kegiatan penelitian identifikasi jenis hama dan penyakit pada tanaman bunga mawardidapatkan hasil berupa tabel dibawah ini : 
Florea : Jurnal Biologi dan Pembelajarannya, 8(1), 2021, 52-61

This is an open access article under the CC-BY-SA license (https://creativecommons.org/licenses/by-sa/4.o/) ISSN 2355-6102(print), ISSN 2502-0404(online)

DOI : $10.25273 /$ florea.v8i1.8071

\begin{tabular}{|c|c|c|c|c|c|}
\hline No & $\begin{array}{l}\text { Nama } \\
\text { tanaman }\end{array}$ & Gejala & Hama & & Penyakit \\
\hline 1. & Mawar 1 & - $\quad$ Daun menguning & & & - Tepung Mildew \\
\hline 2. & Mawar 2 & - Daun berlubang & $\begin{array}{l}\text { - Ulat Daun } \\
\text { rubigalis) }\end{array}$ & (Udea & \\
\hline 3. & Mawar 3 & \begin{tabular}{|lr} 
- & Daun \\
titik-titik terdapat & merah \\
kekuningan & atau \\
abu-abu & \\
kecoklatan & \\
- Daun menguning \\
- & Daun berlubang \\
\end{tabular} & $\begin{array}{l}\text { - Tungau(Tetranychus } \\
\text { telarius) } \\
\text { Belalang } \\
\text { nigricornis) }\end{array}$ & (Valanga & - Tepung Mildew \\
\hline 4. & Mawar 4 & $\begin{array}{l}\text { - } \quad \text { Batang } \\
\text { membusuk, pada } \\
\text { batang terdapat } \\
\text { lapisan kerak } \\
\text { berwarna merah } \\
\text { - } \text { Daun menguning } \\
\end{array}$ & & & $\begin{array}{ll}\text { - } & \text { Jamur Upas } \\
\text { - } & \text { Tepung Mildew }\end{array}$ \\
\hline 5. & Mawar 5 & $\begin{array}{lll}\text { Bunga bercak } \\
\text { berwarna perak }\end{array}$ & - Thrips & & \\
\hline 6. & Mawar 6 & \begin{tabular}{|lr} 
- & Bunga \\
berwarna & cousuk \\
dan & terdapat \\
bintik-bintik & \\
hitam pada bunga \\
- & Daun menguning \\
\end{tabular} & & & $\begin{array}{ll}\text { - } & \text { Bunga busuk } \\
\text { - } & \text { Tepung Mildew }\end{array}$ \\
\hline 7. & Mawar 7 & \begin{tabular}{|lr} 
Daun & terdapat \\
titik-titik merah \\
kekuningan \\
abu-abu \\
kecoklatan \\
Batang \\
membusuk, pada \\
batang terdapat \\
lapisan kerak \\
berwarna merah \\
\end{tabular} & $\begin{array}{l}\text { - Tungau(Tetranychus } \\
\text { telarius) } \\
\text { - Jamur Upas }\end{array}$ & & $\bullet$ \\
\hline 8. & Mawar 8 & - Daun menguning & & & - Tepung Mildew \\
\hline 9. & Mawar 9 & $\begin{array}{ll}\text { - } & \text { Daun menguning } \\
\text { - } & \text { Daun berlubang } \\
\end{array}$ & $\begin{array}{l}\text { - } \quad \text { Belalang } \\
\text { nigricornis) } \\
\end{array}$ & (Valanga & - Tepung Mildew \\
\hline 10. & $\begin{array}{l}\text { Mawar } \\
10\end{array}$ & \begin{tabular}{|lr} 
- Daun berlubang \\
Daun & terdapat \\
titik-titik & merah \\
kekuningan & atau \\
abu-abu & \\
kecoklatan & \\
\end{tabular} & $\begin{array}{l}\text { Tungau(Tetranychus } \\
\text { telarius } \\
\text { - Belalang } \\
\text { nigricornis) }\end{array}$ & (Valanga & \\
\hline
\end{tabular}


Florea : Jurnal Biologi dan Pembelajarannya, 8(1), 2021, 52-61

This is an open access article under the CC-BY-SA license (https://creativecommons.org/licenses/by-sa/4.o/)

ISSN 2355-6102(print), ISSN 2502-0404(online)

DOI : $10.25273 /$ florea.v8i1.8071

\section{Pembahasan}

Kegiatan penelitian identifikasi jenis penyakit pada tanaman bunga mawar dilaksanakan di daerah kecamatan Manyaran, Kabupaten Wonogiri, Provinsi Jawa Tengah. Kegiatan penelitian ini dilaksanakan pada selama 2 minggu yaitu pada mulai tanggal 28 November 2020 sampai tanggal 13 Desember 2020.. Proses identifiksi gejala hama dan penyakit pada tumbuhan mawar dilakukan dengan mengambil beberapa sampel tumbuhan mawar yang berada di daerah Kecamatan Manyaran. Penggunaan sampel ini bertujuan

untuk mempermudah dalam proses pengambilan data tumbuhan mawar yang berada di lingkup daerah Kecamatan Manyaran. Kegiatan ini diawali dengan kegiatan observasi. Kegiatan ini meliputi pencarian dan pengidentifikasian tanaman bunga mawar yang teridikasi terkena penyakit. Kemudian setelah diperoleh data, kemudian dilakukan diagnosis penyakit pada tanaman dengan cara mencari dan mencocokkan dengan referensi sumber yang ada.

Dari tabel hasil kegiatan penelitian identifikasi jenis hama dan penyakit pada tanaman bunga mawar, didapatkan identifikasi penemuan-penemuan gejala yang dialami pada bunga mawar.

\section{Mawar 1}

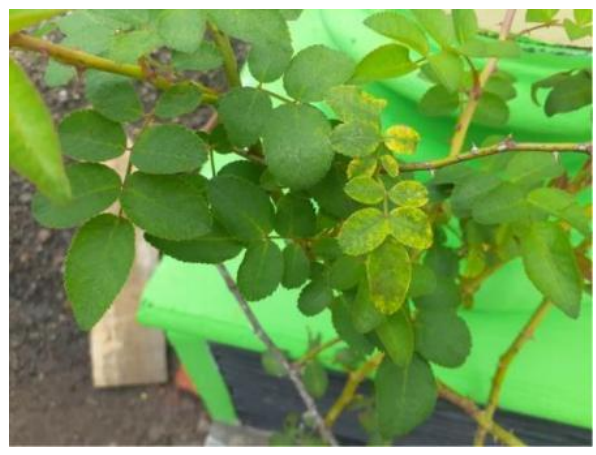

Gambar 1. Mawar 1
Observasi pertama pada tumbuhan bunga mawar 1 ditemukan gejala menguning pada beberapa daun tumbuhan bunga mawar.

Gejala menguningnya daun pada tumbuhan bunga mawar ditandai dengan perubahan warna daun dari hijau menjadi kuning yang dimulai dari sisi luar daun dan menuju ke tengah. Peristiwa menguningnya daun pada bunga mawar setelah diidentifikasi ternyata daun pada tumbuhan bunga mawar tersebut mengalami gejala serangan Penyakit Tepung Mildew.Hal tersebut sesuai pendapat (Ayu, 2016) yang menyatakan bahwa akibat serangan penyakit Tepung Mildew, daun akan menjadi kemerahan, kemudian menguning, dan akhirnya gugur.

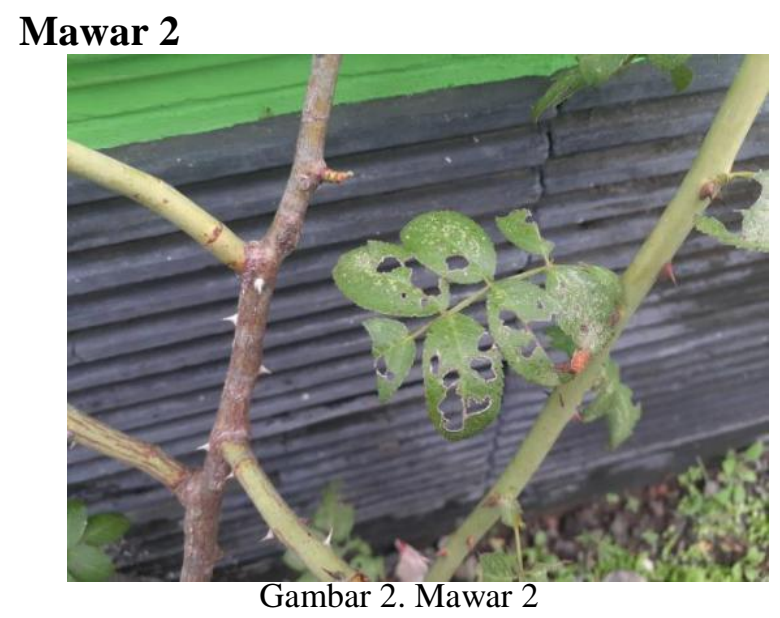

Kemudian observasi pada tumbuhan bunga mawar 2 ditemukan gejala munculnya lubang-lubang yang terdapat pada daun tumbuhan bunga mawar.

Munculnya lubang-lubang pada daun bunga mawar sangat beragam dalam hal bentuk dan jumlahnya pada setiap helai daun. Hal tersebut setelah diidentifikasi ternyata daun pada tumbuhan bunga mawar tersebut mengalami serangan hama Belalang (Valanga nigricornis). Hal tersebut didukung dengan pendapat (Maryani, 2013) yang menyatakan bahwa gejala serangan 
Florea : Jurnal Biologi dan Pembelajarannya, 8(1), 2021, 52-61

This is an open access article under the CC-BY-SA license (https://creativecommons.org/licenses/by-sa/4.o/)

ISSN 2355-6102(print), ISSN 2502-0404(online)

DOI : $10.25273 /$ florea.v8i1.8071

belalang antara lain seperti daun menjadi sobek dan berlubang-lubang besar.

\section{Mawar 3}

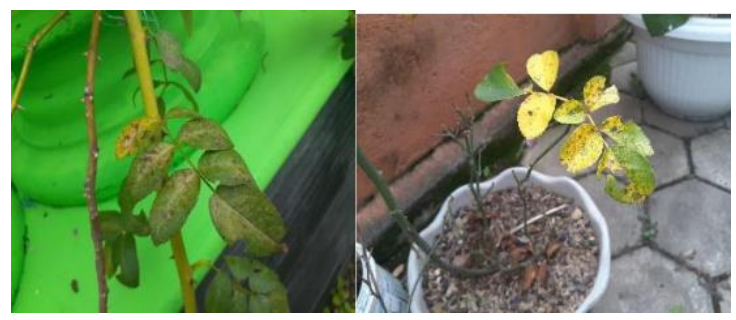

Gambar 3. Mawar 3

Kemudian observasi ketiga pada tumbuhan bunga mawar 3 ditemukan gejala munculnya bercak-bercak merah kecoklatan pada daun tumbuhan bunga mawar dan daun tanaman bunga mawar menguning dan berlubang.

Munculnya lubang-lubang pada beberapa helai daun bunga mawar disebabkan oleh hama belalang, hal ini didukung oleh pendapatnya (Maryani, 2013) yang menyatakan bahwa belalang dapat menyerang tanaman bagian daun yang menyebabkan daun menjadi berlubanglubang.

Selain itu ternyata pada saat kegiatan penelitian ditemukan adanya bercak-bercakbercak merah kecoklatan dengan jumlah dan bentuk yang beraneka ragam pada beberapa helai daun bunga mawar dandiimbangi juga adanya daun berwarna kuning. Setelah diidentifikasi ternyata daun pada tumbuhan bunga mawar tersebut mengalami serangan penyakit Tepung Mildew. Hal ini didukung oleh pendapat (Ayu, 2016) yang menyatakan akibat serangan penyakit tepung mildew ini, daun akan menjadi kemerahan, kemudian menguning dan akhirnya gugur. Penyakit tepung mildew disebabkan oleh jamur Oidium $s p$.

\section{Mawar 4}

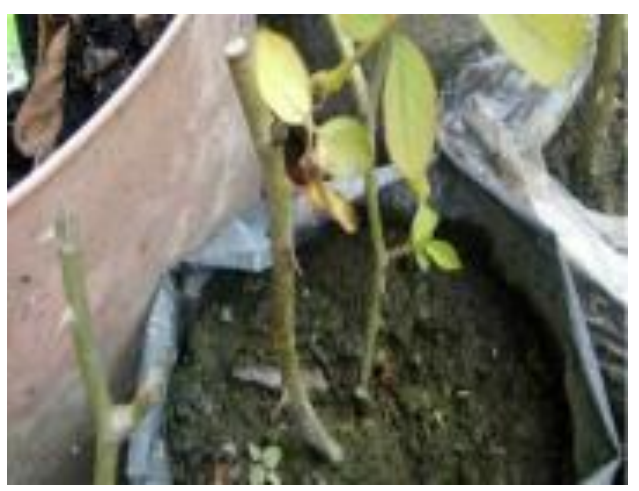

Gambar 4. Mawar 4

Observasi keempat pada tumbuhan bunga mawar 4 gelaja yang terjadi yaitu Batang membusuk, pada batang terdapat lapisan kerak berwarna merah dan daun menguning. Batamg membusuk dikarenakan jamur upas daun menguning dikarenakan terserang penyakit tepung mildew

\section{Mawar 5}

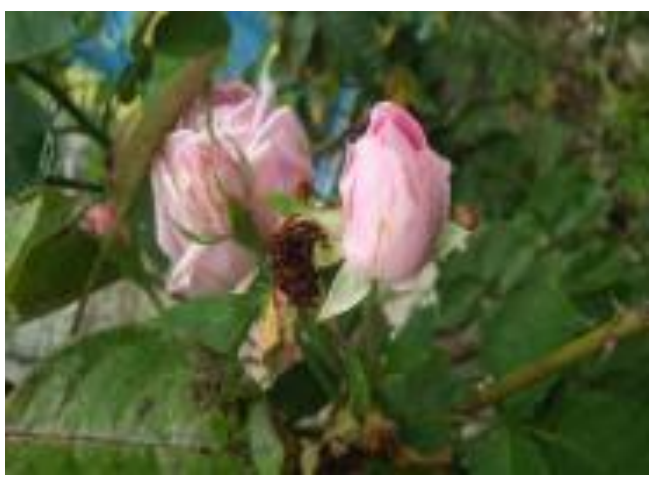

Gambar 5. Mawar 5

Observasi selanjutnya ditemukan hama serangga Thirps pada bunga mawar 5 . Thrips merupakan hama jenis serangga yang menyerang tanaman bunga mawar. Biasanya bunga mawar akan menguning dan kecoklatcoklatan. Thrips sangat menyukai bunga mawar yang berwarna terang. 
Florea : Jurnal Biologi dan Pembelajarannya, 8(1), 2021, 52-61

This is an open access article under the CC-BY-SA license (https://creativecommons.org/licenses/by-sa/4.o/)

ISSN 2355-6102(print), ISSN 2502-0404(online)

DOI : $10.25273 /$ florea.v8i1.8071

Hama serangga Thrips akan menyerang tanaman bunga mawar dengan mengisap cairan sel tanaman. Hal ini sesuai pendapat (Dwiyanti, 2018) yang menyatakan bahwasannya Biasanya hama tanaman ini menghisap cairan pada bunga, daun, dan cabang dari tanaman sehingga menyebabkan tanaman mawar mati.

\section{Mawar 6}

Observasi selanjutnya bunga mawarmengalami pembusukan dan daun menguning. Penyakit busuk bunga disebabkan oleh cendawan yang memiliki nama latin Botrytis cinereadan pada daun disebabkan denganserangan Penyakit Tepung Mildew.

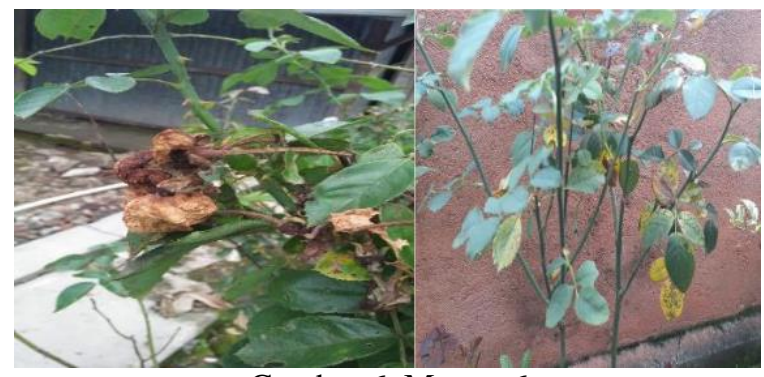

Gambar 6. Mawar 6

Tanaman bunga mawar yang terserang

penyakit ini akan mengalami pembusukan pada kantung bunga, selain itu akan muncul bintil-bintil pada pada kuncup bunga yang akan terbuka. Sedangkan pada daun bunga mawar menguning dikarenakan serangan penyakit Tepung Mildew dan penyakit tersebut dikarenakan jamur Oidium sp.

\section{Mawar 7}

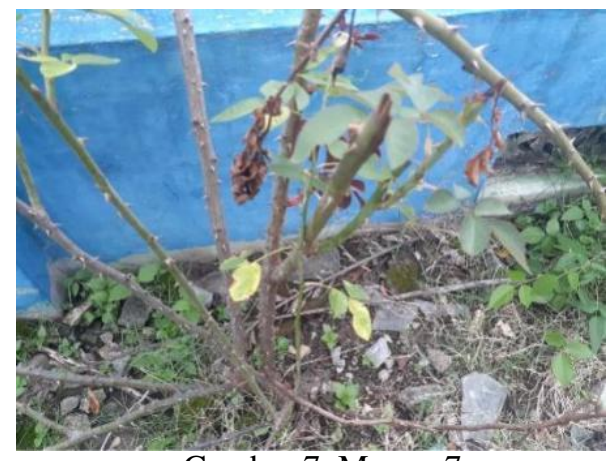

Gambar 7. Mawar 7
Observasi selanjutnya pada tumbuhan bunga mawar 7 ditemukan hama antara lain :

Jamur upas dengan nama latin Corticium salmonicolor merupakan jamur yang sering menyerang pada batang bunga mawar. Tanaman bunga mawar yang terserang jamur upas akan muncul kerak pada batang dan jika lama terserang maka batang akan membusuk dan mati. Dan peristiwa menguningnya daun pada bunga mawar ternyata daun pada tumbuhan bunga mawar tersebut mengalami serangan Penyakit Tepung Mildew.

Sedangkan pada daun tanaman bunga mawar ditemukan adanya bercak-bercakbercak merah kecoklatan dengan jumlah dan bentuk yang beraneka ragam pada beberapa helai daun bunga mawar. Hal tersebut setelah diidentifikasi ternyata daun pada tumbuhan bunga mawar tersebut mengalami serangan Tungau, Tungau merupakan Jenis hama yang seringkali ditemukan yaitu Tetranychus telarius.

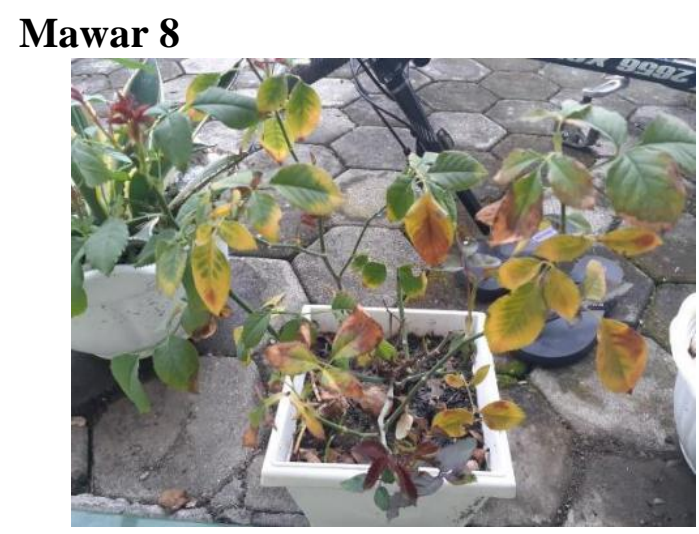

Gambar 8. Mawar 8

Tumbuhan bunga mawar 8 ditemukan gejala penyakit pada daun yaitu daun menguning kecoklatan.

Gejala penyakit pada daun yang menguning tumbuhan bunga mawar terjadi perubahan warna daun dari hijau menjadi kuning yang dimulai dari sisi luar daun dan 
Florea : Jurnal Biologi dan Pembelajarannya, 8(1), 2021, 52-61

This is an open access article under the CC-BY-SA license (https://creativecommons.org/licenses/by-sa/4.o/)

ISSN 2355-6102(print), ISSN 2502-0404(online)

DOI : $10.25273 /$ florea.v8i1.8071

menuju ke tengah. Daun pada tumbuhan bunga mawar tersebut mengalami serangan Penyakit Tepung Mildew.Hal tersebut sesuai pendapat (Ayu, 2016) yang menyatakan bahwa akibat serangan penyakit Tepung Mildew, daun akan menjadi kemerahan, kemudian menguning, dan akhirnya gugur.

\section{Mawar 9}

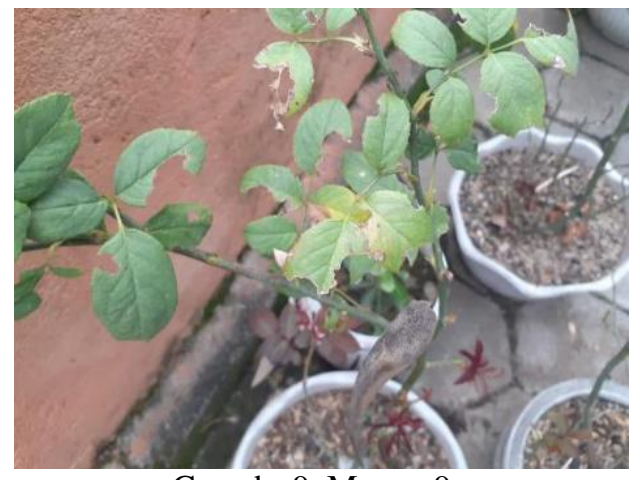

Gamabr 9. Mawar 9

Observasi pada tumbuhan bunga mawar

9 ditemukan gejala menguning dan berlubang pada beberapa daun tumbuhan bunga mawar.

Daun menguning pada tumbuhan bunga mawar tersebut mengalami serangan Penyakit Tepung Mildew.Hal tersebut sesuai pendapat (Ayu, 2016) yang menyatakan bahwa akibat serangan penyakit Tepung Mildew, daun akan menjadi kemerahan, kemudian menguning, dan akhirnya gugur.

Sedangkan adanya lubang-lubang pada daun bunga mawar tersebut mengalami serangan hama Belalang (Valanga nigricornis). Hal tersebut didukung dengan pendapat (Maryani, 2013) yang menyatakan bahwa gejala serangan belalang antara lain seperti daun menjadi sobek dan berlubanglubang besar.

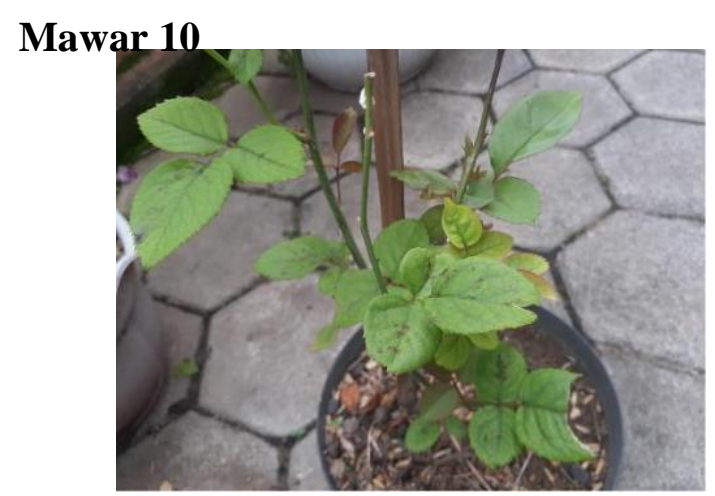

Gambar 10. Mawar 10

Observasi pada tumbuhan bunga mawar 10 ditemukan gejala daun terdapat titik-titik merah kecoklatan dan pada beberapa helai daun terdapat lubang.

Titik-titik merah kecoklatan pada daun bunga mawar ternyata daun pada tumbuhan bunga mawar tersebut mengalami serangan Tungau. Hal ini sesuai pendapat (Hikmah et al., 2018) yang menyatakan bahwa Hama Tungau, jenis hama yang sering kali ditemukan yaitu Tetranychus telarius. Gejala tanaman yang terserang hama ini yaitu ada titik abu-abu kecoklatan pada bagian daun atau pucuk tanaman yang dihisap cairan sel tanaman.

Sedangkan adanya lubang-lubang pada daun bunga mawar tersebut mengalami

serangan hama Belalang (Valanga nigricornis). Hal tersebut didukung dengan pendapat (Maryani, 2013) yang menyatakan bahwa gejala serangan belalang antara lain seperti daun menjadi sobek dan berlubanglubang besar.

\section{KESIMPULAN}

Berdasarkan penelitian yang telah dilaksanakan, maka dapat disimpulkan bahwasannya pada penelitian identifikasi hama dan penyakit pada tumbuhan bunga mawar yang berada di kawasan daerah Kecamatan Manyaran, ditemukan beberapa gejala hama dan penyakit yang muncul pada sebagian besar tanaman bunga mawar diantaranya seperti, menguningnya daun tanaman bunga mawar yang disebabkan oleh 
Florea : Jurnal Biologi dan Pembelajarannya, 8(1), 2021, 52-61

This is an open access article under the CC-BY-SA license (https://creativecommons.org/licenses/by-sa/4.o/)

ISSN 2355-6102(print), ISSN 2502-0404(online)

DOI : $10.25273 /$ florea.v8i1.8071

hama Tepung Mildew; munculnya lubanglubang pada helai daun tanaman bunga mawar yang disebabkan oleh hama ulat daun(Udea rubigalis) maupun hama Belalang (Valanga nigricornis); munculnya titik merah kekuningan atau abu-abu kecoklatan pada daun tanamana bunga

mawar yang disebabkan oleh Tungau(Tetranychus telarius); munculnya kerak berwarna merah pada batang tanaman bunga mawar yang disebabkan karena jamur upas; serta membusuknya pada beberapa bagian tanaman bunga mawar yang disebabkan oleh hama triphs.

\section{DAFTAR PUSTAKA}

Amiarsih, D., Yulianingsih, Y., \& Diharjo,

S. (2006). Pengaruh Jenis Dan

Perbandingan Pelarut Terhadap Hasil

Ekstraksi Minyak Atsiri Mawar. Jurnal

Hortikultura.

https://doi.org/10.21082/jhort.v16n4.20

06.p

Ansori Mattjik Nurhajati.2011.

MembangunUsaha Tanaman Hiasdan

Bunga Potong Dengan Mengaplikasikan

Bioteknoligi Khususnya Kultur Jaringan. 1-62.

AlitFarisi Oria, Alit FarisiTri Handoyo, Distiana Wulanjari, dan Susan Barbara Patricia. 2019. Introduksi Mawar

Potong Untuk Meningkatkan

Pendapatan Petani Mawar Di Desa

Karangpring Kecamatan Sukorambi

Kabupaten Jember.Jurnal Seminar Nasional, 1-4.

Astrilia Damayanti dan Endah Ayu Fitriana Program. (2015). Jurnal Bahan Alam Terbarukan. Jurnal Bahan Alam Terbarukan.

Ayu, A., Setyawan, D., \& Widiyanto, B. (2016). Pengaruh Pemberian Slow Stroke Back Massage Dan Aromaterapi Mawar Untuk Menurunkan Tekanan Darah Pada Pasien Hipertensi Di Rsud H.Soewondo Kendal. Jurnal Ilmu
Keperawatan Dan Kebidanan (JIKK). Bambang Yuwono, Yuli Fauziah, Y. R. S. (2008). Sistem Pakar Berbasis Web Untuk Identifikasi Jenis Dan Penyakit Pada Bunga Mawar. Seminar Nasional Informatika 2008.

Budiarto Kurniawan, Andy Pramurjadi, Idha W Arsanti, Dhani Gartina. 2017. Sistem Pakar Identifikasi Gangguan Organisme Pengganggu Tanaman dan Defisiensi Hara Tanaman Hias Krisan. 68-90

Dwiyanti, A. (2018). Efek Ekstrak Bunga Mawar (Rosa damascena mill)

Terhadap Penyembuhan Angular Cheilitis yang Diinduksi Staphylococcus aureus dan Candida albicans Pada Tikus Jantan Galur Wisata (Ratus norvegicus). Skripsi, 185.

Fahmi Reza. 2018. Pengaruh Media Tanam Terhadap Pertumbuhan Stek Mawar Pagar (Rosa multiflora).1-8.

Farisi, O. A., Handoyo, T., Wulanjari, D., Patricia, S. B., \& Jember, U. (2019). Oria Alit Farisi *, Tri Handoyo, Distiana Wulanjari, Susan Barbara Patricia 2 1. 179-182.

Hikmah, N., Amelia, C. R., \& Ariani, D. (2018). Pengaruh Pemberian Masase Effleurage Menggunakan Minyak

Aromaterapi Mawar terhadap Penurunan Intensitas Nyeri Dismenore pada Remaja Putri di SMK Negeri 2 Malang Jurusan Keperawatan. Journal

Of Issues In Midwifery.

https://doi.org/10.21776/ub.joim.2018. 002.02 .4

Hydrodistillation, M. A. (2015). Jurnal Bahan Alam Terbarukan. Jurnal Bahan Alam Terbarukan.

https://doi.org/10.15294/jbat.v4i1.3769 Irawan Basowi. 2017. Identifikasi Jenis

Bunga Mawar Berdasarkan Tulang Daun. Simki-Techsain, Vol 02 , No. 03, 1-7. 
Florea : Jurnal Biologi dan Pembelajarannya, 8(1), 2021, 52-61

This is an open access article under the CC-BY-SA license (https://creativecommons.org/licenses/by-sa/4.o/)

ISSN 2355-6102(print), ISSN 2502-0404(online)

DOI : $10.25273 /$ florea.v8i1.8071

Kartika Trimin. 2018. Pemanfaatan Tanaman Hias Pekarangan Berkhasiat Obat di Kecamatan Tanjung Batu. Jurnal Ilmiah Matematika dan Ilmu Pengetahuan Alam,Vol, 15 No. 1, 48-55

Mamahit E M Juliet. 2016. Pengendalian Hama Terpadu Tanaman Hias di Desa Kakaskasen Kota Tomohon (Jenis-Jenis Hama pada Tanaman Krisan di Desa Kakaskasen Kota Tomohon). Jurnal LPPM Bidang Sains dan Teknologi, Vol 3, No 1, 81-4

Marlina Nina \& Euis Rohayati. 2009. Teknik Perbanyakan Mawar Dengan Kultur Jaringan. Buletin Teknik Pertanian, Vol 14, No 2, 65-67

Mill,R. (1952). $M A W A R$ ( Rosa damascena Mill. ). 1-18.

Nuraini, Partini partini. 2018. Analisis Usaha Tanaman Hias di Kelurahan Tembilahan Kota Kecamatan Tembilahan Kabupaten Indragiri Hilir. Jurnal Agribisnis Unisi, Vol.7, No.1, 46-57

Proklamasiningsih, E., Budisantoso, I., Kamsinah, Dwiati, M., \& Maharning, A. R. (2016). Penerapan ipteks tanaman mawar bagi masyarakat desa banteran kecamatansumbang.Prosiding Seminar Naisonal "Pengembangan Sumber Daya Perdesaan Dan Kearifan Lokal Berkelanjutan VI, "2(November).

R. Tejasarwana, I.B. Rahardjo. 2009. Pengaruh Formula Pupukdan Jarak Tanam terhadap Hasil Bunga Mawar Potong. J Hort, Vol 19, No 03, 287-293.
Untuk Pengendalian Penyakit Berdasarkan Curah Hujan Pada Mawar. Jurnal Hortikultura. https://doi.org/10.21082/jhort.v17n4.20 07.

Ula Qowiyah Dini, Nur Azizah, dan Agus Suryanto. 2019. Pembungaan Kembali Bunga Mawar (Rossa SP) sebagai Tanaman Taman melalui Pemangkasan dan Pemberian Pupuk. Plantropica Journal of Agricultural Science, Vol 4, No 1, 1-10.

Werdiningsih, H. (2007). Studi Pola Ruang Terbuka Hijau di Lingkungan Perumahan Semarang Studi Kasus Lingkungan Perumahan Graha Taman Bunga BSB. ENCLOSURE.

Y.R.Suradinata, \& A.Wulansari. 2015.Respon Tanaman Mawar Batik Dengan Menggunakan Konsentrasi 1Methylyclopropane (1-MPC) Pada Beberapa Tingkat Kemekaran Bunga. Jurnal Kultivasi.Vol 14, No 2, 1-8

Yuliawan Wendi. 2019. Pertumbuhan Beberapa Bentuk Potongan Pangkal Setek Tanaman Mawar (Rosa sp.) Akibat Cara Aplikasi Zat Pengatur Tumbuh Root-Up. Jurnal Ilmiah Pertanian Paspulum, Vol 7, No 1, 4247

Sari, G. M., Diniarti, F., Sindara, Y., . W., . P., \& Pasmawi, Y. (2018). GO GREEN LABORATORY SEBAGAI SOLUSI MENGURANGI PENYAKIT DEGENERATIF DI DESA SUKARAJA TAHUN 2018. Journal of Nursing and Public Health. https://doi.org/10.37676/jnph.v6i2.650

Suhardi, S. (2007). Efektivitas Fungisida 